\title{
O Sexo Feminino em campanha pela emancipação da mulher"
}

\author{
Cecília Vieira do Nascimento** \\ Bernardo J. Oliveira***
}

\begin{abstract}
Resumo
A despeito do movimento histórico de padronização do comportamento feminino circunscrito ao espaço doméstico, levado a cabo em meados do século XIX, alguns esforços no sentido de promoção do desenvolvimento das potencialidades da mulher, dentro e fora do âmbito familiar, podem ser detectados na imprensa da época. Neste artigo descrevemos o posicionamento do semanário O Sexo Feminino (1873-74), da cidade de Campanha, Minas Gerais, frente ao papel da mulher nas questões políticas, culturais e educacionais, e analisamos algumas de suas estratégias discursivas.
\end{abstract}

Palavras-chave: Imprensa Feminina, O Sexo Feminino, Direitos da Mulher, Trabalho Feminino, Acesso à Ciência.

\footnotetext{
* Recebido para publicação em outubro de 2005, aceito em novembro de 2006.

** Mestre pela Faculdade de Educação da UFMG; ceciliavieira@terra.com.br

***Professor da Faculdade de Educação da UFMG; be@fae.ufmg.br
} 
O Sexo Feminino

Women's empowerment in the nineteenth century Brazilian newspaper O Sexo Feminino

\begin{abstract}
Despite the $19^{\text {th }}$ century historical tendency to restrict women's life to the domestic sphere, some efforts for the empowerment of women could be seen in the press of the period. In this paper we focus on the weekly newspaper $O$ Sexo Feminino, published in Campanha (a rural village of the Brazilian state of Minas Gerais) during 1873-74 and we analyse its discourse concerning the feminist perspective on political, cultural and educational issues.
\end{abstract}

Key Words: Feminist-Press, O Sexo Feminino, Woman's Right, Woman's Work, Popularization of Science. 
No dia 7 de setembro de 1873, começou a circular pelas ruas de Campanha, Minas Gerais, o periódico semanal intitulado $O$ Sexo Feminino. Neste, e nos quarenta e quatro números publicados em seguida, a editora D. Francisca Senhorinha da Motta Diniz e suas colaboradoras - constituidoras de uma pequena elite de mulheres letradas dentro e fora de Campanha tinham como motivação comum a melhoria da condição da mulher na sociedade.

Essas e outras mulheres estavam impulsionadas por um amplo movimento de redefinição da mulher na modernidade $e$ vinham a utilizar-se do meio impresso como espaço para suas várias reivindicações. Depois da experiência em Campanha, onde também lecionava na Escola Normal, Francisca Senhorinha muda-se com suas filhas para o Rio de Janeiro, onde continua a publicar jornais, em meio a uma efervescente imprensa dirigida $e$ editada por mulheres. Ela consolidava caminhos abertos por outras mulheres, que já se aventuravam no campo das publicações jornalísticas. Em 1852, a argentina Joana Paulo Manso de Noronha fundava, no Rio de Janeiro, o Jornal das Senhoras, com o subtítulo Modas, Literatura, Bellas-Artes, Theatros e Crítica. No decênio seguinte, em 1862, aparece o Bello Sexo: Periódico Religioso, de Instrução e Recreio, Noticioso e Crítico Moderado redigido por D. Julia de Albuquerque Sandy Aguiar, também no Rio de Janeiro. Apesar de manter o tom ponderado de seu antecedente, o próprio subtítulo revela que sua aceitabilidade se apoiava em tradições religiosas e moderadas, mas apresenta algumas inovações, como a reunião semanal de suas colaboradoras e artigos assinados - prática incomum no Jornal das Senhoras -, acenando para a maior tolerância da escrita feminina.

Embora imprimisse originalidade argumentativa, O Sexo Feminino apresentava-se com diagramação semelhante à da imprensa do período que, raramente, ultrapassava quatro páginas, com folhas tipografadas. Sua tiragem alcançava média de 800 exemplares (07/09/1874:1) e, após os dez primeiros números do 


\section{O Sexo Feminino}

semanário, foram reimpressos outros $4000 .{ }^{1}$ Uma quantidade significativa para o período, sobretudo se considerarmos o número de leitores e leitoras em potencial, assim como a população da cidade de Campanha. De 20.071 habitantes à época, apenas 1.458 mulheres sabiam ler e escrever em 1872, ou seja, cerca de $7 \%$ da população total (número um pouco superior à diminuta média nacional - 5,5\% do total da população, segundo dados do Recenseamento daquele ano). ${ }^{2} O$ Sexo Feminino atingia, provavelmente, uma razoável porcentagem da população feminina local alfabetizada, assim como um público fora dos limites da cidade. ${ }^{3}$

Francisca Senhorinha mantém-se atuante como jornalista até, pelo menos, 1893, ano em que publicava O Quinze de Novembro do Sexo Feminino. Nossa análise se restringe ao período inicial do semanário e enfoca, sobretudo, seu esforço na promoção da educação feminina e seu novo papel na construção da sociedade moderna.

A materialidade do jornal propicia uma análise das simbologias de gênero, entendendo a condição de ser mulher como uma das formas de se estar no mundo, evitando o sujeito essencializado no feminino (assim como no masculino), mas em constante relação, sendo construído e, portanto, instável (Soihet, 1997). Nesse processo, o feminino é compreendido como sujeito $e$ sujeitado, entre alianças e desavenças, em nome da mudança, mas também da manutenção.

\footnotetext{
1 "Esta reimpressão tem por fim: $1^{\circ}$ - satisfazer às reclamações dos assinantes que exigem os números anteriormente publicados; $2^{\circ}$ - formar séries décuplas que vão ser postas à venda na Corte; $3^{\circ}$ - fazer-se coleção do periódico no fim do ano" (O Sexo Feminino, no $11,15 / 11 / 1873)$.

2 A título de comparação, o índice de homens letrados, em 1872, era cerca de $10 \%$ da população total, segundo dados apresentados por Hahner (2003:75).

${ }^{3}$ Cita-se o registro no jornal, entre outros, de assinantes de Lorena/SP, Rio Preto/SP, Bagagem/MG, Três Pontas/MG, além de permutas com jornais da Bahia, Pernambuco, Santa Catarina, Rio Grande do Norte, assim como de Madrid e Nova York.
} 
A condição a que estava submetida a mulher brasileira, durante o século XIX, era de repressão e submissão, crítica presente em O Sexo Feminino (08/08/1874:1), que compreendia sua situação como a de "traste de casa" - traço que, segundo sua redatora, aproximava ricas e pobres, negras e brancas. Para não serem ignoradas e relegadas à cozinha (como parte do mobiliário) ou, o que era pior, tratadas com brutalidade, foram necessários investimentos em várias frentes que as elevariam ao pedestal de rainhas do lar.

Segundo Maria Beatriz Nizza da Silva (1977:99), a condição da mulher casada, que perdurava no Brasil desde a primeira metade do século XIX, era a seguinte:

(...) a mulher devia obediência ao marido; os filhos deviam obediência ao pai de preferência à mãe; o marido e pai não podiam eximir-se de pagar o sustento da família, fossem quais fossem as suas razões para querer se separar dela. A conduta da mulher obedecia a um controle muito rígido: bastavam umas saídas a passeio para que fosse dada como "perdida", ao passo que a conduta do marido era sempre encarada com benevolência, fosse ele briguento, bêbado ou amancebado. O recolhimento era a pena com que os poderes públicos puniam a má conduta das mulheres.

Esse quadro nos permite compreender as diversas reivindicações de algumas mulheres, sobretudo a partir das décadas finais dos oitocentos, também presentes em $O$ Sexo Feminino. De acordo com Maria Amélia Teles (1993), o Brasil, durante o século XIX - com destaque para seu último quartel - foi o país latino-americano onde o jornalismo feminista demonstrou maior empenho. ${ }^{4} \mathrm{~A}$ valorização da mulher na esfera doméstica

$4 \mathrm{O}$ feminismo pode ser pensado como movimento social, eclodindo no final da década de 60 em países como E.U.A. e França, e como movimento político, sendo pano de fundo para atuação de diversos grupos de mulheres. Utilizamos da expressão, aqui, com a intenção de demarcar o posicionamento do jornalismo feminino como veículo de defesa de questões entendidas como sendo de 


\section{O Sexo Feminino}

representou requisito fundamental para que a imprensa feminina, progressivamente, reivindicasse novos espaços no mercado de trabalho, assim como maior participação política.

Discursos diversos tentavam conformar a mulher como importante agente civilizatório, tendo no seio familiar seu principal espaço de intervenção social, na condição de esposa e mãe. Para além do reconhecimento e do respeito em âmbito familiar, $O$ Sexo Feminino defendia o desenvolvimento integral das potencialidades da mulher, dentro e fora de casa, além da aquisição de direitos que lhe possibilitariam o domínio de conhecimentos, maior participação nas questões de campo social, assim como a garantia de direitos na esfera política.

Como a escrita era um dos espaços e domínios a ser conquistado pelas mulheres, $O$ Sexo Feminino apresentava-se com certas ressalvas. Uma delas estava relacionada a seu papel no cenário político, no qual se situa neutramente, declarando que "nossa folha não é política" (20/12/1873:2). A afirmação de tal posição, no entanto, deve ser vista como estratégia. Considerando o verdadeiro ostracismo feminino no universo da política, bem como a dilatada negativa ao domínio da palavra - inclusive escrita -, era natural que suas redatoras fossem cuidadosas. Um posicionamento demarcado por questões políticas stricto sensu implicaria limitar ainda mais o número de possíveis leitoras $e$ leitores, que já teriam de se haver com o fato de serem simpáticos às causas femininas.

A neutralidade política do jornal era questionada, inclusive, pelo fato de sua redatora ser casada com o também jornalista e advogado Dr. José Joaquim da Silva Diniz, proprietário do jornal O Monarchista, de Campanha, onde O Sexo Feminino era tipografado. O casamento com um monarquista declarado deveria sugerir, quase que por contágio, sua posição política. Francisca Senhorinha, em algumas passagens do jornal, explicitava simpatia

interesse de algumas mulheres. O ponto de convergência é o questionamento da divisão tradicional entre homens e mulheres. 
pelo Imperador D. Pedro II, enfatizando o que o aproximava de um mecenas: "protetor das letras, e seu mais acérrimo propagador" (20/12/1873:2). Esses elementos serviam como base para o contínuo mal-estar com o editor de $O$ Colombo $^{5}$, jornal campanhense com veio republicano, a quem Senhorinha respondia com veemência: "Não sabemos em que grande república ou republiqueta a mulher deixe de ser escrava, e goze de direitos políticos, como o de votar e ser votada"(20/12/1873:3).

Longe de ser um observador imparcial da dinâmica política de sua atualidade, $O$ Sexo Feminino respirava ares impregnados por questões políticas que, mesmo negadas, se materializava na própria existência do jornal. A escolha da data para a publicação do primeiro número do periódico - 7 de setembro - faz coro com uma correlação constante no jornal - independência política do país e independência da mulher. Narciza Amália, renomada poetisa de Rezende, província do Rio de Janeiro, uma das colaboradoras mais ilustres de O Sexo Feminino, assim entendia:

Do seio dessa terra de Minas, tão rica de seiva e de juventude, do seio dessa terra generosa, que recebeu e fecundou as primeiras idéias de nossa emancipação política, é que devia também partir o primeiro brado pela emancipação da mulher (O Sexo Feminino, 11/10/1873:3).

Com níveis diferenciados de engajamento, o jornal não se furtava às discussões que constituíam a efervescência política do período. Uma questão a ser enfrentada pelas mulheres, segundo o jornal, dizia respeito a sua representatividade nas decisões políticas. Constantes reivindicações junto aos legisladores, de quem $O$ Sexo Feminino cobrava intervenções mais efetivas no que se entendiam ser os interesses da mulher, demarca sua percepção sobre o campo político, entendido como campo de poder. A despeito dessa compreensão, o voto feminino não

${ }^{5}$ Primeiro jornal republicano em Minas, fundado por Francisco Honório Ferreira Brandão. Campanha (1873-1885), segundo Valladão (1947:255). 


\section{O Sexo Feminino}

aparece explicitamente em seu horizonte de reivindicações, senão como um ideal ainda distante. É o que se percebe quando o jornal trata, com certa ironia, do descaso dos homens quanto à votação das mulheres, sobre o direito de

votarem e serem votadas, que é o que aliás constitui verdadeira utopia na atualidade, e enquanto os homens não forem anjos; mas entretanto, permanece $e$ vai continuando na representação da tal farsa eleitoral (14/01/1874:2).

De maneira sutil, Francisca Senhorinha desenhava argumentos de sustentabilidade daquilo que viria a ser uma de suas principais frentes, ou seja, o sufrágio feminino. Em publicações subseqüentes, com destaque para $O$ Quinze de Novembro do Sexo Feminino (1889/1893), em um contexto mais propício ao movimento feminista, ela assumia, de forma contundente, sua posição favorável ao voto da mulher. Essa mudança sugere o próprio movimento vivenciado pela sociedade brasileira que, em meados do século XIX, alimentada por ares de liberdade e igualdade, buscava constituir a imprensa como um lócus privilegiado de ampliação democrática, inclusive no que se refere ao sufrágio feminino e que, já no período republicano, com o fortalecimento do meio impresso, contava também com a ajuda de outras frentes de defesa pelo voto, inclusive das associações femininas.

O direito ao voto da mulher era entendido como um desejo utópico, sobretudo se considerarmos que, nos primeiros anos da década de 1870, o número de eleitores era pequeno e, mesmo entre a maioria dos homens, era um direito ainda por se conquistar, pois exigia uma renda mínima e um certo grau de alfabetização. A exemplo de outras Constituições latinoamericanas, as leis brasileiras não faziam menção proibitiva, de forma direta, ao voto da mulher, uma vez que o título de cidadão era concedido somente aos homens - o que, segundo Branca 
Alves (1980), demonstra o nível de menosprezo pela figura feminina. ${ }^{6}$ Contudo, não faltava fôlego para que algumas mulheres, através da imprensa, reivindicassem participação em outros níveis, que dariam contornos de legitimidade à sua atuação política que culminaria no voto feminino nas décadas seguintes. Sua causa feminista se fortalecia à medida que se solidarizava com argumentações em favor de uma sociedade mais igualitária, como no que se referia aos escravos. Sem matérias específicas, a escravidão aparecia no jornal, em momentos pontuais, como uma prática incompatível ao mundo civilizado. Assim, pode-se ler no editorial de 20 de setembro de 1873:

Não há maior erro, mais triste ingenuidade do que dizer-se que o século XIX é o século das luzes, existindo a escravatura $e$ a pena de morte, os dois maiores crimes do mundo bárbaro, ainda conservados no mundo civilizado.

Com a proibição do tráfico negreiro no Brasil, em 1850, acelerou-se a luta pela libertação dos escravos, contando com uma adesão bastante significativa de algumas mulheres que, em décadas seguintes, chegaram a organizar sociedades abolicionistas. De acordo com Maria Amélia Teles, a forma participação das mulheres abolicionistas denunciava sua própria condição de subordinação:

Elas colaboraram nas atividades que garantiam a infraestrutura da campanha, como vender doces e flores para levantar finanças ou tocar piano e cantar nas festas realizadas em prol do movimento abolicionista (Teles, 1999:28).

${ }^{6}$ É curioso perceber que algumas mulheres valeram-se dessa abertura legal para reivindicarem o direito ao voto nas décadas seguintes, o que rendeu muita polêmica, obrigando os legisladores a reverem o corpo da lei e estabelecerem expressamente a proibição ao voto da mulher. Cf. Alves, 1980. 


\section{O Sexo Feminino}

Narcisa Amália, uma das poetisas colaboradoras de O Sexo Feminino era uma abolicionista simpatizante de Nísia Floresta, que defendeu a abolição da escravatura, ao lado da proposta republicana e de educação e emancipação da mulher. Contudo, em seus escritos publicados no periódico, ela não utilizava a plataforma anti-escravagista. A maneira pouco expressiva como a questão da escravidão aparece nos números iniciais de $O$ Sexo Feminino, nos dá a dimensão de como a imprensa ainda gestava tais discussões, que foram tomando corpo, sobretudo na década de 1880 , o que se reflete inclusive em publicações subseqüentes do jornal.

O jornal dedicou maior atenção à pena de morte, trazendo para suas páginas um caso emblemático que apontava elementos de barbaridade, insistentes em permanecer na sociedade, dificultando o triunfo da tão propalada civilização. Um dos casos é digno de nota, pois seu tratamento pelo Sexo Feminino nos permite ressaltar como algumas estratégias da luta pela abolição se conjugavam com a reafirmação do papel da mulher na sociedade. Trata-se do caso do carrasco Fortunato, criminoso que livrou-se da morte aceitando ser o executor de outros condenados à forca. Por um longo período, Fortunato havia sido algoz de muitos criminosos na província mineira. Sem mais serventia na província, e sem meios legais que lhe destinassem outra vida, ele permanecia preso, símbolo vivo de um tempo em que a espada prevalecia sobre a razão. Tempo este que se pretendia distante, porém persistia em se fazer presente. O pedido da província do Rio de Janeiro para que lá fossem utilizados os seus préstimos evidencia essa permanência. Realizada sua missão sangrenta em terras fluminenses, inicia-se a polêmica sobre o destino de Fortunato.

O Sexo Feminino defendia que ao carrasco fosse dada a liberdade para que buscasse o perdão junto a Deus e à sociedade, por tantas mortes que carregava. É interessante notar a estratégia do artigo de Senhorinha (08/11/1873:02-3) que, em nome das mães de família de sua cidade e de toda a província mineira, intervém junto ao Imperador $e$, ardilosamente, à Imperatriz. 
Quando seus argumentos se construíam com base no pedido de clemência para o algoz, dirigia sua fala à Imperatriz, em um explícito apelo à sua condição de mulher piedosa. Sensibilizandose em nome de uma vida humana, como em uma prece onde se roga à Virgem Maria que intervenha junto a Jesus Cristo pelos oprimidos, espera-se da Imperatriz que exerça seu instinto materno, mesmo como esposa, e influencie favoravelmente na decisão do Imperador. Essa apelação reflete a perspectiva da editora d'O Sexo Feminino acerca do papel da mulher na sociedade: mensageira do bem público, personificação da civilização. Reconhecidos seus instintos maternais, sua natural aptidão para o cuidado, necessitava oferecer-lhe instrumental para que potencializasse sua intervenção social de forma racionalizada, instruída, ilustrada. Nesse sentido, O Sexo Feminino apresentavase como importante veículo instrumentalizador na busca pela ampliação do campo de domínio feminino e, por conseguinte, estimulava a diminuição da "grande desigualdade de condições civil e política entre os dois sexos no Brasil” (27/12/1873:2), por meio da consolidação de uma prática que almejava tornar constante na sociedade: o posicionamento da mulher frente às questões de interesse social.

\section{Instrumentalizando a atuação feminina}

Uniam-se forças em favor da consolidação de direitos civis, meta para a qual a redatora dedicava especial atenção. Estimulado por um protesto assinado por mulheres portuguesas contra o casamento civil, no final da década de 1860 - documento que circulava pela imprensa brasileira, copilado por alguns jornais -, O Sexo Feminino prontifica a fazer-se de intermediário entre os favoráveis $e$ os contrários a tal casamento, disponibilizando seu jornal como porta-voz de um assunto reiteradamente interpretado como de interesse social, possivelmente visando angariar maior confiança do público e mais leitores. 


\section{O Sexo Feminino}

A discussão sobre o casamento $\mathrm{civil}^{7}$, temática privilegiada de $O$ Sexo Feminino, pode ser interpretada como uma convergência de interesses do semanário. Ao mesmo tempo em que contribuía para o debate de um assunto atual e abrangente, o jornal promovia a prática das mulheres se posicionarem publicamente, especialmente no que tangia seus interesses. Ao fazer isso se afirmava como porta voz da causa feminina e veículo de aperfeiçoamento da dinâmica social. No incitamento às discussões entre as mulheres $e$ a seu posicionamento público, o jornal visava também demonstrar a atuação e participação conseqüente da mulher nos assuntos de interesse da sociedade, almejando maior visibilidade civil (Bresciani, 1992). ${ }^{8}$

Fruto dessa reivindicação parece ter sido o pedido de algumas mulheres para responder pessoalmente pela assinatura do jornal, sem o intermédio do marido. "Está encetada uma vultosa correspondência entre as senhoras que reclamam a remessa desta folha diretamente a elas, e não por intermédio dos maridos" (O Sexo Feminino, 07/01/1874:4). Elas queriam demonstrar que a desigualdade entre os sexos estava centrada menos em aspectos naturais, sendo antes reflexo de um longo alijamento da educação, argumento reforçado, inclusive, no posicionamento de alguns jornalistas adeptos da educação feminina. O jornal República ${ }^{9}$, do Rio de Janeiro, em 24 de setembro de 1873, saudando o aparecimento de $O$ Sexo Feminino, parabenizava Senhorinha por sua iniciativa, reconhecendo as dificuldades para a instrução da mulher:

\footnotetext{
${ }^{7}$ No Brasil, o casamento civil só foi promulgado, através do decreto $\mathrm{n}^{\circ} 181$, em 24 de janeiro de 1890.

8 Stella Bresciani utiliza-se dessa expressão para problematizar a exclusão feminina dos direitos políticos, no Brasil e na Europa, no século XIX e início do XX.

9 Órgão do Partido Republicano, do Rio de Janeiro, com o qual O Sexo Feminino mantinha estreitos vínculos.
} 
Cecília Vieira do Nascimento e Bernardo J. Oliveira

sua linguagem de sobra demonstra que as faculdades intelectuais da mulher em nada são inferiores às do homem.

O que mais do que ela teria feito um homem, professor na cidade da Campanha?! E demais, para que em nosso país uma senhora ache-se habilitada a entrar nas lutas da imprensa, quanto não lutou para adquirir instrução, cercada como está de um ambiente opressor, cheio de preconceitos, de falta de recursos de todo o gênero para o sexo feminino (...). ${ }^{10}$

Defesas como esta ganham maior dimensionamento na leitura de jornais contemporâneos de O Sexo Feminino. É fácil perceber que a simpatia demonstrada pelo República estava longe de ser regra na imprensa de domínio masculino. Eram constantes publicações jornalísticas que, mesmo demonstrando aparente cordialidade, permaneciam enraizadas em uma mentalidade de recusa à ampliação do campo de atuação da mulher. Nesse aspecto, $O$ Colombo parece ser um dos mais entusiastas em criticar as pretensões de $O$ Sexo Feminino.

Queremos que antes e acima de tudo a mulher seja verdadeiramente a mulher: - saiba ser filha, esposa e mãe, e não descure o aprender a costurar, cozinhar, lavar $e$ engomar, para poder tornar-se perfeita dona-de-casa cuja administração interior lhe será subordinada.

Isso antes de tudo. Depois então, a instrução: e quanto mais farta, melhor.

Querer fazer das mulheres verdadeiros homens, reservando sem dúvida para estes (homens) o governo da casa, como parece pretender O Sexo Feminino, é inverter as leis da natureza, e tirar da mulher aquele doce perfume de candidez, de modéstia e de pudor que Deus lhe deu e pelo qual tem ela sempre conquistado a estima, os respeitos e a

\footnotetext{
${ }^{10}$ Trecho reproduzido do jornal República, por O Sexo Feminino, de 04 de
} outubro de $1873, \mathrm{n}^{\circ} 05, \mathrm{p} .03$. 


\section{O Sexo Feminino}

veneração da humanidade.(...) Livre-nos Deus de mulheres sábias: matou-as Molière com aquela sua apreciadíssima e sempre nova comédia das Preciosas Ridículas $(O$ Colombo, 14/09/1873).

Os argumentos do editor de O Colombo são ilustrativos de um ambiente misógino, de pouca receptividade às idéias de Senhorinha, entendidas como portadoras de uma inversão de papéis naturalmente designados aos sexos. ${ }^{11}$ Entretanto, também revela que $O$ Sexo Feminino não era encarado como mero veículo de capricho feminino, passatempo e diversão de mulher pretensiosamente intelectualizada, mas, antes, porta-voz de um potente interventor na dinâmica social.

Não é sem motivo que se recupera Molière para se questionar a empreitada jornalística de Senhorinha. A preocupação em colocar a mulher no lugar devido, ou seja, o destinado pelos homens é fundamentalmente pertinente em Preciosas Ridículas. As preciosas Madalena e Catarina personagens femininas da peça - se vêem em sérios problemas ao questionarem a autoridade do pai Gregório e seu arranjo matrimonial, assim como por se ocuparem de enfeites $e$ sentimentalidades. Gregório concluía:

(...) e vós, futilidades pomadas e pinturas!... versos $e$ nulidades!... sonetos e sonatas... e outras mais diabruras,

\footnotetext{
${ }^{11}$ Livre-nos Deus de mulheres sábias: assim indica que o século XVII havia ficado não só nos registros teatrais, mas também na mentalidade da sociedade. A retratação de Molière que, apesar de peça escrita há mais de dois séculos (1654), nos dizeres de $O$ Colombo, constituía-se em sempre nova representação da figura feminina, reforçava o enraizamento da mentalidade sobre a mulher. Por outro lado, nota-se que o nascimento do periódico não passou em brancas nuvens, sendo a preocupação do redator desabonar as causas pelas quais lutava O Sexo Feminino, indicando a iminência do perigo de estar nas mãos de uma mulher um promissor veículo de divulgação, como o impresso - sobretudo, se demonstrasse boa articulação e lucidez de propósitos como fazia Senhorinha.
} 
Cecília Vieira do Nascimento e Bernardo J. Oliveira

que as moças arrastais a só fazer loucuras! (...) Seja o vosso destino arder no fogo eterno!... (Moliére, 1957).

Consciente da enraizada associação entre mulher e vaidade, O Sexo Feminino fazia desse combate uma de suas principais frentes, denunciando a aceitabilidade da mulher em sua inferiorização social. A mulher deveria perceber-se como ser independente e deveria se preparar para isso. Alcançaria a maioridade abandonando futilidades pueris corporificadas pela vaidade excessiva.

O jornal deprecia o excesso de zelo com a aparência. "O luxo e a vaidade, eis o seu apanágio! Eis a sua única aspiração sobre a terra!" (14/09/1873). Essa atitude representava um empreendimento fadado à eterna objetivação da mulher que, preocupada com sua ornamentação externa, secundarizaria o que de mais importante constituiria a nova mulher: sua educação. A vaidade feminina aparece como um sério obstáculo à sua racionalidade, levando a redatora a responsabilizá-la pelos maus casamentos e pelos infortúnios em família, por isso devidamente recalcada pelo jornal. ${ }^{12}$

Em vez de formar seu coração para a virtude, de fazê-la conhecer seus deveres, de ornar-lhe o espírito com conhecimentos que a livrem do enojo, habituam-na ao gosto do enfeite e da vaidade, e só cuidar das graças do corpo desprezando os ornatos internos do espírito, $e$ as qualidades do coração (...) completamente ignorantes do que devem a Deus, a si mesmas e à sociedade.

\footnotetext{
${ }^{12}$ Apesar de não explicitados pelo jornal, alguns aspectos específicos estavam relacionados ao apelo à participação mais consciente da mulher na sociedade, como a referência ao aleitamento materno, prática sabidamente rejeitada pelas mulheres do século XIX. Em 1873, o médico José Pereira Rego proferia palestra na Academia de Medicina, em discurso incentivador para que as mulheres não se "deixem subjugar pelos caprichos da moda e prazeres sociais", em detrimento de aleitarem seus filhos (apud Veiga, 2004:54).
} 


\section{O Sexo Feminino}

Só lhes falam de modas, divertimentos, bailes, reunióes, espetáculos (...) (23/05/1874:2, grifos nossos).

Além disso, Senhorinha estava atenta para o fato de que a vaidade excessiva da mulher, valorizada e até estimulada pelo homem, atraído por sua ornamentação externa, apresenta-se em um círculo vicioso como argumento para justificar uma possível debilidade feminina. Esse ponto de vista identifica homens $e$ mulheres como indivíduos deformados pelos costumes sociais. Tal círculo se quebraria à medida que a mulher se conscientizasse dessa realidade e passasse a uma atitude menos passiva.

Diante da constante negativa masculina em ver na mulher uma igual, esta deveria agir de modo a comprovar suas aptidões racionais, preparando-se por meio de uma educação e instrução acuradas, em uma espécie de transição do requinte do corpo ao requinte do espírito. O Sexo Feminino construía um sujeito identificado, sobretudo, por sua condição de devedor. A busca pela legitimidade da igualdade de suas condições racionais trazia, em seu bojo, uma carga de incorporação de responsabilidade, pela mulher, pelo bem estar da sociedade. Como tática de convencimento, Senhorinha incorpora, ao mesmo tempo em que constrói, para o feminino o lugar do equilíbrio, da benevolência, enfim, da civilidade. Esses termos aparecem no jornal de forma recorrente, revelando uma tentativa de reforçar um pertencimento e uma natureza feminina.

Em um artigo intitulado "O que queremos?", O Sexo Feminino lamenta o estado de ignorância de direitos em que vive a mulher.

Queremos a nossa emancipação - a regeneração dos costumes;

Queremos reaver nossos direitos perdidos;

Queremos a educação verdadeira que não se nos tem dado a fim de que possamos educar também nossos filhos;

Queremos a instrução pura para conhecermos os nossos direitos, e deles usarmos em ocasião oportuna; 
Cecília Vieira do Nascimento e Bernardo J. Oliveira

Queremos conhecer os negócios de nosso casal, para bem administrarmo-los quando a isso formos obrigadas;

Queremos enfim saber o que fazemos, o porquê e o pelo quê das coisas;

Queremos ser companheiras de nossos maridos, e não escravas;

Queremos saber o como se fazem os negócios fora de casa;

Só o que não queremos é continuar a viver enganadas (25/10/1873:2).

Nessa passagem, Francisca Senhorinha explicita a legitimidade dos direitos femininos. Com a retomada dos direitos supunha-se alcançar a propalada emancipação da mulher. Tratava-se de reaver os direitos e não propriamente de conquistálos. A estratégia discursiva remete à necessidade de reconhecimento de direitos naturais que vinham sendo negados ou desrespeitados, como a liberdade usurpada dos povos escravizados.

\section{Transpondo o espaço da casa: o direito ao trabalho remunerado} e o acesso à ciência

Em estudo sobre a parcela da população excluída dos direitos políticos nas sociedades européias e no Brasil do século XIX e início do XX, Stella Bresciani (1992) aponta para o trinômio que sintetiza o conjunto das reivindicações femininas, em nome de sua emancipação, no decorrer desse período, ou seja, a instrução, os direitos políticos e os direitos civis. Em maior ou menor grau, $O$ Sexo Feminino reproduz tais reivindicações, particularmente o acesso às profissões, sobretudo às ditas profissões liberais, como uma importante bandeira de luta.

A despeito de sua enraizada missão doméstica, a inserção no mundo das profissões aparece ora com tonalidades mais discretas, ora como direito negado às mulheres, mas sempre como importante alternativa à sua escravização no lar. Assim, as colaboradoras de O Sexo Feminino contestavam o lugar da casa 


\section{O Sexo Feminino}

como reduto da mulher, cenário naturalmente destinado ao dispêndio de suas energias: o "deserto em que vivemos (...) onde o destino decretou-nos a residência" (08/08/1874:1).

A discussão sobre a participação consciente da mulher na sociedade ganha relevo quando se discute sua instrução. Por mais que esteja presente o atrelamento entre educação e ilustração, como meio de tornar a mulher uma companhia mais agradável ao homem e de maior utilidade na formação de seus filhos, não podemos desconsiderar seu caráter emancipatório. A instrução viabilizaria sua emancipação, seja por meio de sua participação social, seja por um trabalho remunerado.

Os trabalhos tradicionalmente ocupados por mulheres eram impregnados por um duplo problema: algumas vezes a empurravam para a reclusão da vida privada - como no caso das costureiras, bordadeiras, roceiras, que, apesar do não comprometimento moral de suas atividades, não lhes permitiam romper com o estigma de inferioridade -, outras eram ocupações ilícitas: da mulher pública. Assim adjetivado, o trabalho feminino fora do seio doméstico era apresentado com uma forte carga de amoralidade, como as prostitutas $e$ as donas de bordéis. Os trabalhos tradicionais femininos estavam atrelados à mera sobrevivência humana, suprindo as necessidades de manutenção da vida, ao passo que, na nova sociedade da qual $O$ Sexo Feminino era mensageiro, esses atributos eram insuficientes.

A busca por alternativas de trabalho era uma tentativa de rompimento e de expansão da casa - lugar de produção da vida $e$, portanto, dos ofícios relacionados à esfera do privado - para a apropriação e o domínio da ação pública, através do pensamento cultivado, em um processo de ampliação de suas perspectivas profissionais e intelectuais. O Sexo Feminino considerava a necessidade de ampliação desses espaços em função de maior visibilidade civil, preparando a mulher intelectualmente. Como representante da elite intelectualizada de sua cidade, o jornal atua no sentido de fazer com que as funções femininas fossem 
associadas a novos domínios, diferentes dos já enraizados no imaginário social.

Médicas, advogadas, escritoras, professoras secundárias, telegrafistas eram constantemente mencionadas pelo jornal, que publicava a luta de mulheres pela participação em concursos públicos, assim como sua inserção em cursos superiores pelo mundo, ao passo que protestava contra a exclusão feminina das instituições de ensino superior. O acompanhamento sistemático e entusiástico de cada nova inserção das mulheres em faculdades induzia ao debate sobre a temática, amadurecendo a pretensão que viria a constituir-se em possibilidade, em 1879, com a Lei de Reforma do Ensino Superior e, anos mais tarde, com a primeira mulher a formar-se em medicina no Brasil em $1887 .{ }^{13}$

O Sexo Feminino tinha consciência das barreiras à formação superior, entre elas, a necessária estruturação em níveis primário e secundário de ensino:

Mas no Brasil em geral, e especialmente nesta grande e opulenta província, tudo está ainda por fazer: nem cursos científicos, nem colégios de artes, nem mesmo escolas primárias regularmente montadas (20/01/1874:2).

Garantindo instrução que habilitasse as mulheres para o trabalho, a intenção era "abrir-lhes todas as carreiras que suas condições físicas e morais as tornam aptas para ocupar" (20/12/1873:3). O jornal não negava as diferenças entre os sexos, pois resguardava os tradicionais bastiões masculinos: o militar, o político e o religioso (Perrot, 1998).

As senhoras, suposto não fossem destinadas para as armas, nem para a magistratura, e ministério da igreja, não têm,

\footnotetext{
${ }^{13}$ Rita Lobato Velho Lopes graduou-se na escola de medicina da Bahia, seguida, em 1888, por Ermelinda Lopes de Almeida, graduada pela escola de medicina do Rio de Janeiro. No mesmo ano, 1888, outras duas brasileiras receberiam o diploma de direito, segundo dados de Hahner (2003:149-150).
} 
O Sexo Feminino

contudo, ocupações menos importantes para o bem geral da sociedade (O Sexo Feminino, 25/10/1873:3).

A formação feminina para o trabalho não colocaria em risco sua natureza de mulher, que $O$ Sexo Feminino resguardava com a promoção das qualidades femininas:

(...) é extremamente satisfatório ver-se que o progresso intelectual efetua-se sem perder terreno, $e$ sem que as qualidades femininas tenham de algum modo enfraquecido. A cultura do espírito não faz a mulher sair de sua esfera. Torna-a sim um ser mais nobre, mais sábia, melhor, e mais amável (28/01/1874:1).

A inserção das mulheres nas profissões possibilitaria a ampliação de seu campo de atuação que, por sua vez, permitirlhes-ia maior independência da figura masculina $e$ até proporcionaria a possibilidade de fazer fortuna. Como, narra entusiasticamente Senhorinha, havia ocorrido com a renomada escritora George Sand que, "com a pena na mão" e trabalhando intelectualmente, faturou uma fabulosa quantia inimaginada para o universo doméstico da mulher que, "ainda que vivesse duas vidas de cem anos jamais chegaria a ganhar com o trabalho físico" (O Sexo Feminino, 28/03/1874:4). Esta e outras narrativas de mulheres bem-sucedidas fora do âmbito doméstico tinham a pretensão de emular mulheres que, "desprendendo-se do comum do nosso sexo" (01/11/1873:3), induziriam outras à identificação com modelos alternativos ao da mulher de alcova.

De toda sorte, percebem-se ainda, no jornal, resquícios de secundarização do trabalho da mulher. Sua atuação aparece como uma garantia, caso depare com a necessidade, na ausência do marido, em uma espécie de "seguro de vida". Nesse caso, sua produtividade mantém-se extrínseca, sob proteção e tutela masculina: 
Cecília Vieira do Nascimento e Bernardo J. Oliveira

habilitadas as mulheres para tais misteres ficarão muitas das que não precisam de ocupar-se com os negócios puramente domésticos, as aptas para exercer profissões que atualmente são afeitas ao sexo masculino, sem que haja repugnância para que o sejam aos indivíduos do sexo feminino (01/01/1874:2, grifo nosso).

Uma análise mais atenta dos diversos artigos publicados em O Sexo Feminino revela que suas reivindicações quanto à capacidade intelectual feminina, assim como em relação ao trabalho, ganhavam corpo nas discussões referentes ao acesso da mulher à ciência.

O tema Ciência parece reunir coisas distintas - instrução, conhecimentos, posturas, planos de reordenamento social - que encarnam um conjunto valores, como progresso, racionalidade, modernidade, vistos como fundamentais para a construção de um país civilizado. Nesse contexto, a mentalidade científica significava a valorização das capacidades individuais em oposição aos privilégios de nascimento. $\mathrm{O}$ poder baseado em parentes ou na riqueza passa a subordinar-se ao mérito dos indivíduos, decorrente principalmente de aptidões intelectuais.

Nesse sentido, o desenvolvimento de uma cultura científica era atitude política, uma forma de fazer com que o país apressasse a marcha do progresso de forma a tomar parte da história universal. Mas não é qualquer ciência que encarna esses ideais. De acordo com O Sexo Feminino, há uma "ciência dos homens" que deveria ser suplantada por uma outra, mais universal, fraternal, útil e promissora. A ciência dos homens caracterizada como aristocrática, elitista, despreocupada com o bem-estar social, perpetua a inferioridade da mulher. O jornal parece ressoar aqui a crítica à ciência togada, essencialmente livresca e vinculada aos arranjos de títulos imperiais ${ }^{14}$, dos bacharéis de direito e dos médicos. Reage, sobretudo, ao discurso médico que distorcia a

${ }^{14}$ Em arena como a dos militares e engenheiros era mais visível e tensa essa oposição aos bacharéis. 


\section{O Sexo Feminino}

figura da mulher como fisiologicamente debilitada, excluindo-a e justificando sua falta de acesso ao conhecimento acumulado pela humanidade.

Segundo o jornal, a ignorância feminina tinha como fundamento a ciência produzida pelos homens, retrógrada e estacionária, que ia de encontro a sua própria função de progresso:

há um reduto onde traiçoeiro reside o inimigo que procuramos combater; esse reduto chama-se - a ignorância da mulher; esse forte que urge metralhar é definido pela ciência dos homens (21/09/1873:1).

Uma ciência segregacionista, masculina, propriedade de poucos aristocratas da inteligência, não tinha valor $e$, nesse sentido, exercia função contrária à sua natureza, que era justamente a de aproximação, unificação intelectual e material. A outra ciência - não somente reservada às mulheres, mas a todos seria mais prática, mais objetiva $e$, sobretudo, mais aberta à inclusão de novos agentes considerados por suas próprias capacidades. Daí a importância da instrução pública, e da difusão da nova mentalidade, vista como mais científica.

O jornal propunha a difusão do conhecimento científico em nome de uma sociedade mais unida e fraterna: "A educação é um adorno desde os mais ricos palácios até a mais humilde choupana de um paupérrimo camponês" (04/10/1873:2). A idéia da extensão dos saberes elementares para toda a população parte do processo de modernização e a difusão da ciência seria uma forma de unir homens e mulheres, sábios e ignorantes.

Se todos compreendessem a utilidade da instrução da mulher entre nós (...) a ciência não formaria sem dúvida uma espécie de aristocracia da inteligência, e o homem, que, logo na infância, não encontra outro guia senão sua mãe, se tornaria mais apto, para o desenvolvimento na viagem, que, neste mundo, faz do seu nascimento ao 
túmulo. Então veríamos a sociedade mais unida pelo laço da igualdade intelectual e dissipada mais ou menos certa repulsão que existe entre o sábio e o ignorante, pelo acanhamento orgulhoso deste e desenvolvimento fraternal daquele (09/05/1874:3).

A popularização da ciência através de jornais e revistas tem seu auge neste último quartel do século XIX em países como França e Inglaterra (Bensaude-Vicente, 1997). O Sexo Feminino buscava estar, e se mostrar, em sintonia com o resto do mundo, por exemplo, através de correspondência com o editor do jornal $O$ Novo Mundo, produzido em Nova York pelo brasileiro José Carlos Rodrigues, de 1870 a 1879. Escrito em português e voltado para os brasileiros que estudavam nos Estados Unidos, O Novo Mundo e sua política de troca com outros jornais brasileiros foi responsável pela veiculação de $O$ Sexo Feminino, mesmo que em pequeno número, para aquele continente, estabelecendo uma rede de sociabilidade de idéias e discussões comuns.

Mas a popularização não se dá unicamente, nem principalmente, pela transmissão de informações científicas, mas pela difusão da autoridade da ciência como perspectiva promotora de harmonia social, veículo de regeneração moral. O principal é a legitimação de seu papel modernizante e civilizatório. Assim, O Sexo Feminino, em suas referências a nomes e saberes, não se preocupa em fazer distinção entre literatos humanistas $e$ cientistas, mas insiste no poder libertador da postura científica, mais objetiva e racional.

Ao convocar a participação de novos agentes, O Sexo Feminino reserva às mulheres contribuição especial. $\mathrm{O}$ jornal não apenas reivindica para a mulher a propriedade da razão e parte ativa na ciência, defendendo a equivalência de suas virtudes intelectuais, mas aponta características que lhes conferem vantagens extras.

Temos toda a certeza de que os homens sobremodo sabem que as mulheres têm a necessária capacidade intelectual 
O Sexo Feminino

para aprender todas as ciências que se lhes queiram ensinar $e$ que, mais do que eles, têm a precisa paciência para estudos superiores como o sejam: os da física, da farmácia, da medicina e de outras disciplinas, cuja ciência, ao menos elementarmente, é de indeclinável necessidade para a vida, crescimento e desenvolvimento do ente racional para que possa atingir o grau de perfectibilidade que lhe destinou o Criador (07/01/1874:2).

Arquitetado no sentido de convencer que a mulher detinha capacidades cognitivas tanto quanto, ou até superiores, os homens, $O$ Sexo Feminino associa à mulher, complementarmente, características como persistência, paciência e dedicação.

Bom é que os homens vão aprendendo com as lições da experiência (...) que elas (as mulheres) têm um cérebro igual ao do sexo contrário e que, às vezes, é ainda mais perfeito e completo para receber a ciência (28/01/1874:4).

Ao constatar que a inferioridade feminina advém unicamente de sua educação, ou da falta dela, O Sexo Feminino propõe que se ofereçam às meninas as mesmas oportunidades de formação intelectual existentes para os meninos e que a ciência, entendida como importante domínio intelectual, seja igualmente acessivel a ambos os sexos. Aumentar o conhecimento e estimular a moralidade eram vistos como aspectos interdependentes da educação. Dissociado do ideal de desenvolvimento moral e de melhoria da humanidade, o aumento do conhecimento, por si só, não teria valor. A observância dos deveres morais apresenta centralidade na educação, assim como o objetivo e propósito do ensino de tornar as pessoas melhores e membros mais úteis à sociedade.

Vale a pena ressaltar que a ciência moralizante, engrenagem de ordenamento social, não é concebida como algo divergente da religião. A configuração da religião como bálsamo da ciência está 
presente em diversas passagens do jornal que, em sua constituição, pretende fazer-se veículo propagador de uma ciência virtuosa, de uma racionalidade que tenha a moralidade como princípio fundante. A vinculação dessa ciência virtuosa com a religião parece-nos, entretanto, especialmente intrincada.

O jornal afirma partir do princípio de que não há saber maior e mais importante do que o saber divino, e parece acreditar que, aproximando-se da sabedoria oriunda da religião, o ser humano estaria no caminho do conhecimento. O Sexo Feminino se opunha, assim, à desvinculação desses saberes e buscava dissolver a crítica conservadora que via no progresso da ciência um passo para a ausência de religião. Além disso, é latente sua preocupação com os estragos que uma ciência que não estivesse em sintonia com idéias moralizantes poderia causar.

Embora cite a asserção de Francis Bacon - "a religião é o preservativo contra a corrupção da ciência" (12/03/1874:3) -, parece-nos que a perspectiva do jornal se aproxima mais do positivismo comtiano. O filosofo inglês do século XVII propunha a separação entre ciência da religião como forma de conhecimentos que, mesmo convergentes ao final, não deveriam ser confundidas, pois tinham métodos, objetos e estilos distintos. Na perspectiva positivista, no entanto, a verdadeira ciência é como uma nova religião. É dela que podemos esperar o amor, a ordenação e o progresso da humanidade. Essas referências não devem ser entendidas como alinhamento do jornal a alguma dessas correntes de pensamento. A visão de ciência expressa n'O Sexo Feminino é eclética, como em tantos outros veículos de vanguarda do período, misturando um genérico apelo à observação da natureza a aspectos do evolucionismo e do positivismo, sem maiores distinções. É importante ressaltar que o denominador comum está na defesa do papel civilizatório da ciência: "É a ciência e não a espada que incumbe decidir as mais implicadas desavenças humanas" dizia o jornal (14/09/1873:1). Bem conduzida, a ciência poderia servir como instrumento, inclusive, para humanizar pessoas corrompidas pela perversão. A característica fundamental 


\section{O Sexo Feminino}

da cultura científica a ser disseminada é a modernização dos costumes sociais e a religião não é vista como um empecilho à racionalização modernizadora da sociedade. Todavia, vale notar que, embora o jornal seja publicado no contexto hegemonicamente católico, não há maiores referências à igreja católica, seus rituais ou sua ação social.

Os cientistas aparecem ora como portadores de uma divindade compartilhada, ora como meros homens que não devem ousar querer assemelhar-se a Deus.

Quanto às obras primas dos homens são grosseiras comparadas com as da natureza! Essa multidão de descobertas admiráveis que fazem cotidianamente nossos sábios na química, na física, nas ciências naturais, não lhes ensinarão jamais a criar um mosquito, um ramo de erva, uma mosca (20/09/1873:4).

O que em princípio pode parecer um paradoxo faz coro com o propósito de reforçar a valorização, senão restrição, de um conhecimento marcadamente moralizante.

Associando religião e progresso científico, O Sexo Feminino objetivava assegurar à pessoa humana a posse de si mesma. Todavia, essa autonomia não pode ser confundida com a ampliação de comportamentos toleráveis; ao contrário, a associação ciência-religião permitiria uma dupla finalidade: o progresso material $e$ intelectual da humanidade, oportunizado pelo primeiro $e$, não menos importante, garantiria eficazes dispositivos de regulação social, passando pelo rigoroso crivo da religião.

A Igreja e a escola são duas antíteses, são duas doutrinas, dois elementos de perfeição moral que se completam.

A instrução é o complemento da religião. Quanto mais iluminada for a inteligência do homem, mais fácil lhe será a compreensão do Ente Superior e das sublimes maravilhas 
Cecília Vieira do Nascimento e Bernardo J. Oliveira

com que a natureza escreve e exalta o seu nome

$(13 / 06 / 1874: 4)$.

\section{Considerações finais}

Tendo visto o posicionamento do jornal frente a questões políticas, culturais e educacionais, lançando-se como órgão civilizador, em oposição à barbárie da pena de morte, da manutenção da escravidão, bem como a sua luta pelo acesso ao saber, da maior representatividade política e social da mulher, podemos considerar que $O$ Sexo Feminino utilizava-se de estratégias discursivas, voltadas para a defesa da causa feminina, articuladas a outras mais amplas. A mulher instrumentalizaria a ampliação de seu campo de atuação na sociedade por meio de atitudes de maior responsabilidade social, reiteradas por $O$ Sexo Feminino.

Em $O$ Sexo Feminino percebemos diferenciações $e$ variações do padrão historicamente produzido que identifica a formação e educação da mulher ao ideário monolítico de reclusão domiciliar. Através da valorização da mulher no desempenho do papel materno e no reconhecimento de sua intervenção moralizadora no seio da sociedade, a mulher reivindicava para si, através da imprensa, a conquista de uma centralidade que desconhecia até então. Esse discurso de promoção da mulher teria sido o "pontapé inicial" para posteriores conquistas de espaços até então exclusivamente destinados ao sexo masculino. Para além da afirmação de um novo perfil no interior da família, suas reivindicações foram se complexificando em sua progressiva inserção pública, transformando-se em luta política pela conquista de sua cidadania, transpondo o espaço da casa, pleiteando outros, como as instituições de ensino superior e os espaços profissionais. 
O Sexo Feminino

\section{Referências bibliográficas}

Alonso, A. Idéias em Movimento: a geração 1870 na crise do BrasilImpério. São Paulo, Paz e Terra, 2002.

Alves, B. M. Ideologia e feminismo: a luta pelo voto no Brasil. Petrópolis, Vozes, 1980.

Bensalde-Vincent, Bernardette; RASmussen, A. (eds.) La Science Populaire dans la Presse et L'edition: XIXe et XXe Siècles. Paris, CNRS, 1997.

Bresciani. Maria Stella Martins. O Anjo da Casa. História e Perspectiva. Uberlândia, v.07,p.191-223, jul./dez, 1992.

CostA, Jurandir Freire. Ordem Médica e Norma Familiar. Rio de Janeiro, Graal, 1989.

ElIAS, Norbert. O processo civilizador. $2^{\mathrm{a}}$ ed. Rio de Janeiro, Jorge Zahar, 1994.

HAHNER, June Edith. Emancipação do Sexo Feminino: a luta pelos direitos da mulher no Brasil. 1850-1940. Florianópolis/Santa Cruz do Sul, Ed. Mulheres/EDUNISC, 2003.

MATOS, Sônia Missagia de. Repensando Gênero. In: AUAD, Sylvia M. A. $\mathrm{V}$. Mulher - cinco séculos de desenvolvimento na América. Belo Horizonte, Federação Internacional de Mulheres da Carreira Jurídica, CREZ-MG/Centro Universitário Newton Paiva-IA/MG, 1999.

Molière. Preciosas Ridículas. Rio de Janeiro, Civilização Brasileira, 1957.

NizzA SILVA, Maria Beatriz. Cultura e Sociedade no Rio de Janeiro (1808 - 1821). São Paulo/Brasília, Ed. Nacional/INL, 1977.

PALlARES-BuRKE, Maria Lúcia. A imprensa periódica como uma empresa educativa no século XIX. Caderno de Pesquisa, n 104 , Faculdade de Educação/USP, jul. 1998, pp.144-161.

PerRot, Michelle. Mulheres Públicas. São Paulo, Editora UNESP, 1998.

SOIHET, Rachel. História, Mulheres, Gênero: contribuições para um debate. In: AguiAR, Neuma. (org.) Gênero e Ciências Humanas: desafio às ciências desde a perspectiva das mulheres. Rio de Janeiro, Record/Rosa dos Tempos, 1997. 
Cecília Vieira do Nascimento e Bernardo J. Oliveira

TelEs, Maria Amélia de Almeida. Breve história do feminismo no Brasil. São Paulo, Brasiliense, 1993.

VAlladão, Alfredo. Campanha da Princesa. Rio de Janeiro, Leuzinger, 1947, Vol. IV.

VEIGA, Cynthia Greive. Infância e modernidade: ações, saberes e sujeitos. In: FARIA FILHO, Luciano Mendes de. (org.) A infância e sua educação, materiais, práticas e representações. Belo Horizonte, Autêntica, 2004, pp.35-82.

\section{Jornais}

O Colombo, $\mathrm{n}^{\circ}$ 36. Campanha, 14 de setembro de 1873, Hemeroteca de Belo Horizonte.

O Sexo Feminino. Campanha da Princeza, 1873/74. Biblioteca Nacional, Rio de Janeiro. Obras Raras. 